\title{
Anatolia
}

\section{The Impact of Technology in Hotels: A Case Study of Istanbul and Ankara Hotels}

\section{CIHAN COBANOGLU , ILHAN DEMIRER , BERKAN KEPECI \& SEVKIYE SIPAHIOGLU}

To cite this article: CIHAN COBANOGLU, ILHAN DEMIRER, BERKAN KEPECI \& SEVKIYE SIPAHIOGLU (2006) The Impact of Technology in Hotels: A Case Study of Istanbul and Ankara Hotels, Anatolia, 17:2, 318-322, DOI: 10.1080/13032917.2006.9687193

To link to this article: http://dx.doi.org/10.1080/13032917.2006.9687193

曲 Published online: 01 Aug 2011.

Submit your article to this journal $₫$

Џll Article views: 85

Q View related articles $₫$

47 Citing articles: 1 View citing articles 지 
Scheyvens, R. (1999). Ecotourism and the Empowerment of Local Communities, Tourism Management, 20: 245-249.

Sexton, W.T. (1998). Ecosystem Management: Expanding the Resource Management 'Tool Kit'. Landscape and Urban Planning, 40: 103-112.

Shafer, C.L. (1999). National Park and Reserve Planning to Protect Biological Diversity: Some Basic Elements, Landscape and Urban Planning, 44: 123-153.

Sia, A. (1997). Loving nature to death, The Star, 26th August.

Stecker, B. (1996). Ecotourism: Potential for Conservation and Sustainable Use of Tropical Forests. A Case Study on the National Parks Taman Negara and Endau-Rompin in Malaysia. Eschborn, Germany: GTZ and TÖB.

Wan-Sabri, W.M., Ahmad, S., Abdullah, M. and Zahid, E. (1991). Socio-economic Status of the Local Population in Upper Tembeling, Taman Negara. Research Thrust Outdoor Recreation, Urban Forestry and Tourism Development Report 1, July 1991. Department of Forest Management, Universiti Pertanian Malaysia.

Weber, B.E. (1968). A National Park System for West Malaysia. Kuala Lumpur: Peace Corps Volunteer.

Hin Wai Yip , Department of Forest Management, Faculty of Forestry, Universiti Putra Malaysia, 43400 UPM Serdang, Selangor, Malaysia. E-mail: yiphinwai2000@yahoo.com

Submitted : 23 June 2006

Resubmitted : 21 August 2006

Accepted : 24 August 2006

\title{
The Impact of Technology in Hotels: A Case Study of Istanbul and Ankara Hotels
}

\author{
CIHAN COBANOGLU \\ University of Delaware \\ ILHAN DEMIRER \\ Texas Tech University \\ BERKAN KEPECI \\ Bilkent University \\ SEVKIYE SIPAHIOGLU \\ Bilkent University
}

\section{INTRODUCTION}

Information technology(IT) has played an increasingly important and dominant role in every part of life, both personally and professionally (Kluge 1996). As a result, technology has become extremely important for the hospitality industry. In the lodging industry, product differentiation through marketing has become challenging. As product differentiation and marketing become more complicated, lodging properties have been forced to consider quality of service as a major competitive factor (Marshall 1988; Reid and Sandler 1992). 
Researchers such as Reid and Sandler (1992) concluded that lodging companies use technology to improve guest satisfaction. Similarly, David, Grabski and Kasavana (1996) suggested that "hotel companies believed that information technology helped improve the quality of business operations" (p.68).

The purpose of this study was to assess the factors that impact the utilization of technology currently used by Istanbul and Ankara Lodging properties. The objective of this study was to report information that would be useful to lodging operators who are confronted by the need to make decisions regarding the use of technology in their properties. The information discovered through this study will be used to help to produce a report and training program concerning the utilization of technology applications in lodging operations.

\section{LITERATURE REVIEW}

Technological advancements in the world influenced hospitality and tourism business as well as all other businesses. Technology has become a major factor in the operation of hospitality businesses with the blossoming of the telecommunications industry, advancements in computer capabilities, and the development of sophisticated software to support delivery of services (Olsen and Connolly 2000). Van Hoof, Collins and Combrink (1995: 64-69) have put it that: "As we enter the next millennium, technology will have a profound impact on our personal and professional lives." As is reputed to be the world's largest industry (O'Connor 1999), tourism industry could not remain negligent of these advancements in the technology that reshaped the production and delivery systems of most businesses. Further, IBM's branch of Travel and Transportation in 1996 published that overall spending in tourism industry for IT exceeds far \$35 million US dollar; and aims of these fund allocations of companies for IT expenditures were assumed to be entering the new markets, meeting the guest expectations and reaching the guests with the appealing rates (IBM Travel and Transportation 1996). Poon (1993) describes the use of computers in hotels as core information processing centers of marketing and distribution, front office, back office and food \& beverage control. According to Poon (1993), information technologies are diffusing in eight key areas of hotel operations:

- Marketing, distribution, reservation and sales,

- Telecommunications,

- Guest accounting,

- Rooms management,

- Back office operations,

- Food and beverage control,

- Energy management,

- Safety and security control. 
Even though, researchers suggested that technology was an essential and integral part of hotel business (Olsen and Connolly 2000; Siguaw, Enz and Namasivayam 2000), not all hotels were utilizing technology fully, therefore, not taking advantage of it (Avgoustis et al. 2003). This study attempted to explore the use of technology in four and five star hotels in Istanbul and Ankara, Turkey.

\section{METHODOLOGY}

A self-administered, cross sectional, online questionnaire containing three sections was established and distributed to 93 five and four-star hotels (census) in Istanbul and Ankara. The first section of the questionnaire listed 20 statements regarding technology use in hotels and asked the level of agreement (5-point Likert Scale) of the managers. The second section listed thirty-five technology applications and asked managers if they utilized or did not utilize each technology application listed in their property. If they did not use the technology application, they were asked to identify the reasons: not needed, too expensive, and/or not familiar with the technology.

\section{DISCUSSION OF FINDINGS}

Thirty-two hotels filled out the questionnaire, yielding 34 percent $(n=32)$ response rate. Majority of the respondents were male $(87.5 \%)$; had bachelors degree $(53.1 \%)$, and hold a position in IT management $(68.8 \%)$. Thirteen $(40.63 \%)$ of the properties that filled in the questionnaire are located in Istanbul and the remaining $19(59.38 \%)$ properties are located in Ankara. Fifteen $(46.87 \%)$ of these 32 hotels identified themselves as 4-star hotels, while $17(53.12 \%)$ described themselves 5-star hotels.

Respondents' Agreements with Technology Statements: The level of agreement with the statements was determined by utilizing a scale ranging from 1 (Strongly Disagree) to 5 (Strongly Agree). A strong majority of the respondents, 20 (62.50\%) strongly agreed with the statement that well-run lodging properties make full use of technology available. All of the participants recognized that internet is a powerful tool for marketing purposes (Mean=4.59).

Utilization of Technology Applications: The most used five technology applications in respondent properties are electronic mail $31(96.88 \%)$, internet access $31(96.88 \%)$, property management system $31(96.88 \%)$, yield management software $31(96.88 \%)$, and fax $30(93.75 \%)$. The least frequent technology implementations due to being too expensive included handheld devices for POS $8(25 \%)$, interactive guide (TV based) $4(12.5 \%)$, electronic in-room safes 2 $(6.25 \%)$, pay per view $2(6.25 \%)$ and central reservation system $2(6.25 \%)$. The least implemented technology applications due to being not familiar with technology included guestroom security panel $5(15.63 \%)$, remote check-in/ out station $4(12.50 \%)$, wireless internet access $4(12.5 \%)$, intranet $4(12.5 \%)$, and preventive maintenance $2(6.45 \%)$. 


\section{CONCLUSION}

This study attempted to find out the perceived impact of technology in Istanbul and Ankara hotels. The managers' statements indicated that they agreed strongly with the fact that technology has a positive impact on the efficiency of the organization, productivity of the employees. However, there were some barriers to using technology in their properties. The main barriers were the cost of the technology, lack of technology strategy within the hotel management, and lack of information about current and new technologies. Handheld devices for POS, interactive guide (TV based), electronic in-room safes, pay per view and central reservation systems are not in use for lodging properties because they are deemed as being too expensive. Handheld devices for POS, voice mail, sales interface with PMS, intranet and purchasing interface with POS are not considered as essential component of service, so they are least frequently used. Guestrooms security panel, remote check-in / check-out, intranet, interactive guide and silent alarm systems are least used technologies due being unfamiliar with the technology.

Based on the findings of this study, the following recommendations may be offered: 1) Both executives and employees might be given technology training to efficiently use the current technology in the property. 2) Technology should not be seemed as a cost but should be seemed as a means for efficiency. 3) Technology infrastructure in the properties should be improved and so more consistent and fast service level could be achieved.

\section{REFERENCES}

Avgoustis, S. Cobanoglu, C. Connolly, D., Hamilton, M. \& Lee, C. (2003). Strategic Uses and Future Directions of IT in the Lodging Industry : 2nd Annual Multi-Unit Lodging Industry Technology Study, Hospitality Technology Magazine, 6 (9).

Buhalis, D. (1998). Strategic Use of Information Technologies in the Tourism Industry, Tourism Management, 19: 409-421.

David, S. J., Grabski, S. \& Kasavana, M. (1996). The Productivity Paradox of Hotel-Industry Technology, Cornell Hotel and Restaurant Administration Quarterly, 37: 64-70.

Hoof, V. H., Collins, G. \& Combrink, T. (1995). Technology Needs and Perceptions, Cornell Hotel and Restaurant Administration Quarterly, 36: 64-69.

IBM Travel and Transportation (1996). The Impact of Information Technology on Travel and Transportation. Retrieved from the Web on March 12, 2005. http://wwweurope.ibm.com/go/ travel/index.html

Kluge, A. E. (1996). A Literature Review of Information Technology in the Hospitality Curriculum, Hospitality Research Journal, 19: 45-64.

Marshall, A. (1988 September, 5). Guest Service Should be more than just Friendly Smiles, Hotel and Motel Management, 203, 32.

O'Connor, P. (1999). Electronic Information Distribution in Tourism and Hospitality. Wallingford: CAB International.

Olsen, M. D. \& Connolly, J. D. (2000). Experienced-based Travel, Cornell Hotel and Restaurant Administration Quarterly, 41(1): 30-40.

Poon, A. (1993). Tourism, Technology and Competitive Strategies. Wallingford: CAB International. 
Reid, D. R. \& Sandler, M. (1992). The Use of Technology to Improve Service Quality, Cornell Hotel and Restaurant Administration Quarterly, 33: 68-73.

Siguaw, J A., Enz, C. A. \& Namasivayam, K. (2000). Adoption of Information Technology in U.S. Hotels: Strategically Driven Objectives, Joumal of Travel Research, 39: 192-201.

Cihan Cobanoglu, Hotel, Restaurant, and Institutional Management, University of Delaware, 14 W. Main St. Raub Hall, Newark, DE 19711, USA. E-mail: cihan@udel.edu

\section{Assessing a River Tracing Behavioural Model: a Taiwan Example}

TSUNG HUNG LEE

National Yunlin University of Sclence and Technology

\section{INTRODUCTION}

Taiwan, located along the fault line separating the Euro-Asian and Philippine continental plates, is affected by frequent plate collisions resulting in an extremely mountainous topography. These mountainous areas receive sufficient rainfall to sustain the flow of water in stream, waterfalls, canyons, cliffs, creeks and rivers (Hsu 1987). River tracing, a sport in adventure tourism, is defined as the practice of following rivers up the sides of mountains, wading through small rapids and climbing over rocks and other obstacles in order to venture into pristine environments. River tracing has recently become a popular activity in adventure tourism and is fast becoming popular in Taiwan as well (Lin 2002).

Ajzen (1985) developed the theory of planned behaviour, which assesses attitudes towards a behaviour, subjective norms and perceived behavioural controls together affect behavioural intention and behaviour. Attitudes comprise cognitive, affective, and behavioural components. The intent behind an attitude can affect external behaviours (Azjen 1991). Subjective norm is defined as an individual's normative belief in a particular referent, weighted by the motivation to express the subjective norm through that referent, which affects behavioural intention (Ajzen 1991). Perceived behavioural control is the expression of an individual's control beliefs weighted by the perceived facilitation of external factors such as sufficient resources, time and money, and internal factors such as ability, skill, information, and willpower. Perceived behavioural control has a direct effect on subsequent behaviour. It also has an indirect effect on behaviour through behavioural intention (Ajzen 1991). Numerous studies using the 